\title{
A Macrodynamics of Debt Regimes, Financial Instability and Growth ${ }^{\star}$
}

\author{
Gilberto Tadeu Lima \\ University of São Paulo \\ Department of Economics \\ São Paulo - Brazil \\ giltadeu@usp.br
}

Antonio J. A. Meirelles

State University of Campinas

Department of Food Engineering

São Paulo - Brazil

tomze@ceres.fea.unicamp.br

Abstract: It is developed a dynamic macromodel of utilization and growth of productive capacity, in which the supply of credit-money is endogenous and firms' debt position - and thus the financial fragility of the economy à la Hyman Minsky - is explicitly modeled. The rate of interest is set as a markup over the base rate, which is exogenously determined by the monetary authority. Banking markup varies with changes in economic activity, which is measured by capacity utilization, while firms' debt position varies with the rates of interest, profit and capital accumulation. Regarding dynamics, it is shown the possibility of relating the stability properties of a system with the interest rate and the debt ratio as state variables to the type of minskyan regime - hedge, speculative, Ponzi - which prevails.

Key words: debt regimes; financial instability; growth

Resumo: Desenvolve-se um modelo dinâmico de utilização e crescimento da capacidade produtiva, no qual a oferta de moeda de crédito é endógena e o endividamento das firmas e, portanto, a fragilidade financeira da economia à Hyman Minsky - é explicitamente modelado. A taxa de juros é determinada através de um mark-up sobre a taxa básica fixada pela autoridade monetária. O mark-up bancário varia com mudanças no nível de atividade econômica, medido pela utilização da capacidade produtiva. Por seu turno, o grau de endividamento das firmas varia em função das taxas de lucro, de acumulação de capital físico e de juros. Em termos dinâmicos, mostra-se que é possível relacionar as condições de estabilidade do sistema formado pelas variáveis taxa de juros e endividamento das firmas ao tipo de regime minskyano - hedge, especulativo ou Ponzi - prevalecente.

Palavras-chave: regimes de endividamento; instabilidade financeira; crescimento

JEL classification: E12; E22

Classificação Anpec: Área 3 - Finanças

- We are grateful to Duncan Foley and Pasquale Commandatore for useful comments. Research funding by the Brazilian National Council of Scientific and Technological Development (CNPq) should be as well gratefully acknowledged. 


\section{Introduction}

The paper develops a macrodynamic model of utilization and growth of productive capacity, in which the supply of credit-money by the banking system at any point in time is endogenous, demand-driven at an exogenously given nominal interest rate. The underlying presumption is that at any given point in time banks are price makers and quantity takers in their markets for loans, whereas price takers and quantity makers in the markets where they raise funding.

Moreover, firms' debt position with the banking system - and therefore the financial fragility of the economy à la Hyman Minsky - is explicitly modeled. To the extent that saving is generated by and concurrently with investment, the choice variable is investment rather than saving. Actually, investment demand is financed by credit-money generated by entrepreneurial borrowing from the banking system and not by any prior saving. Following the financial instability view developed by Minsky $(1975,1982)$, the capital development of the market economy is therefore conceived of as being accompanied by exchanges of present money for future money. The present money pays for resources that are used in the production of investment output, while the future money is the amount of profits that will accrue to firms as their capital assets are used in production.

As a result of the process by which investment by producing units is financed, the liabilities on their balance sheet determine a series of prior payment commitments, while their assets generate a series of conjectured cash inflows. With investment being financed by credit-money generated by entrepreneurial borrowing from the banking system, the flow of money to firms is a response to expectations of future profits, while the flow of money from firms is financed by profits that are actually realized.

The interest rate is set by the banking system as a markup over the base rate, which is exogenously determined by the monetary authority. Over time, while the banking markup varies with changes in productive activity, which is measured by capacity utilization, the base rate remains unchanged. Admitedly, the banking markup is influenced by a whole set of determinants - bank characteristics, macroeconomic conditions, explicit and implicit taxation, overall financial structure, and underlying regulatory and institutional framework. For tractability, however, we focus solely upon the influence exerted by the rate of capacity utilization. The assumed constancy of the base rate implies that changes in the interest rate are driven solely by changes in the banking markup. Nevertheless, it will be seen that the behavior of this simplified model is complex enough and gives rise to several possibilities. Since we intend to focus on the flexibility of the banking markup and also to derive as many definite results as possible, we do not incorporate a policy rule for the base rate.

Moreover, it is formally derived a version of the minskyan taxonomy of financing regimes (hedge, speculative, ponzi) by firms, whose debt position varies according to the rates of interest, capital accumulation and growth. What then follows is a detailed analysis relating the dynamic stability properties of a system having the nominal interest rate and the debt to capital ratio by firms as state variables to the type of minskyan finance regime that is prevalent in the productive sector. For instance, it is derived that a long-run equilibrium solution with hedge finance will be stable only in case banking markup is procyclical and the interest rate is lower than the growth rate, while a long-run equilibrium solution with ponzi finance will be necessarily unstable. 
The remainder of the paper is organized as follows. Section 2 describes the structure of the model, whereas Section 3 analyzes its behavior with respect to the determination of capacity utilization and growth. In turn, Section 4 develops a formalization of the minskyan taxonomy of financing regimes, while Section 5 relates the dynamic stability properties of the mcroeconomy to those regimes. The closing section summarizes the main conclusions derived along the way.

\section{Structure of the model}

We model an economy that is closed and has no government fiscal activities. A single good that can be used for both investment and consumption is produced with two factors of production, capital and labor, which are combined through a fixed-coefficient technology. To the extent that technological change is abstracted from, these coefficients are assumed to remain unchanged. ${ }^{1}$

Production activity is carried out by oligopolistic firms. They produce - and hire labor - according to demand, it being considered only the case in which there is not enough demand to ensure full capacity utilization at the ongoing price. Hence, firms are assumed to hold idle physical capital. ${ }^{2}$ Firms also make investment plans, which are described by the following desired investment function:

$$
g^{d}=\alpha+\beta r-\gamma i
$$

where $\alpha, \beta$ e $\gamma$ are positive parameters, and $g^{d}$ is the desired investment as a ratio of the existing physical capital stock, $K$. In turn, $r$ is the rate of profit defined as the flow of money profits generated by physical capital, $R$, divided by the value of capital stock at output price, while $i$ is the interest rate. We follow Rowthorn (1981) and Dutt (1990), who in turn follow Kalecki (1971) and Robinson (1962), in assuming that desired investment depends positively on the profit rate. As regards the negative dependence of investment on the interest rate, we follow Dutt (1994).

\footnotetext{
${ }^{1}$ A post-keynesian dynamic macromodel of capital accumulation, growth and distribution in which labor-saving technological innovation plays a pivotal role is developed in Lima (2000). The rate of innovation is made to depend non-linearly on market concentration, thus incorporating a possibility raised in the neo-schumpeterian literature on the double-sided relation between industrial dynamics and technological change. An alternative specification of endogenous technological change can be found in Lima (2003), where labor-saving innovations by firms depend non-linearly on distribution itself, the idea being that functional distribution determines both the incentives to innovate and the availability of funding to carry it out. In both cases, the non-linear nature of the model gives rise to multiple equilibria and endogenous, self-sustaining fluctuations.

${ }^{2}$ For Steindl (1952), firms plan idle capacity so as to be ready for a sudden expansion of sales. First, the existence of fluctuations in demand means that the producer wants to be in a boom first, and not to leave the sales to new competitors who will press on her market when the boom is over. Second, it is not possible for the producer to expand her capacity step by step as her market grows due to the indivisibility and durability of the equipment. Finally, entry deterrence is an issue: if prices are high enough, entry of new competitors is feasible even when required capital is large; hence, the holding of idle capacity allows firms to confront new entrants by suddenly raising supply and driving prices down.
} 
The economy is inhabited by two classes, capitalists and workers. Following the tradition of Marx, Kalecki (1971), Kaldor (1956), Robinson (1962), and Pasinetti (1962), we assume that they have a different saving behavior. Workers, who are always in excess supply, provide labor and earn only wage income, which is all spent in consumption. This assumption that workers as a class do no saving does not, of course, rule out the possibility that individual workers might save. What this view amounts to is the assumption that for workers as a class the saving of some of them is matched by the dissaving of others (Foley \& Michl, 1999). Capitalists, in turn, receive profit income, which is the entire surplus over wages, with productive and financial capitalists both saving constant fractions, $s_{p}$ and $s_{f}$, respectively, of their share in profits. Hence, the functional division of income is given by:

$$
X=(W / P) L+R
$$

where $X$ is the output level, $W$ is the nominal wage, $P$ is the price level and $L$ is the employment level. Hence, financial capitalists' profit income appear as a deduction of the general flow of money profits generated by the stock of physical capital:

$$
r K=r_{p} K+r_{f} K
$$

where $r_{p}$ is the portion of the general rate of profit which accrues to productive capitalists and $r_{f}$ is the portion of the general rate of profit which accrues to financial capitalists.

From eq. (2), the general rate of profit can be expressed as:

$$
r=(1-V a) u
$$

where $V$ is the real wage, $a$ is the labor-output ratio and, therefore, $(1-V a)$ is the profit share in income. Since we assume that the ratio of capacity output to the capital stock is given, we can identify capacity utilization with the actual output-capital ratio, $u=X / K$. For simplicity, we also assume that the profit share in income is given, which implies that changes in the general rate of profit in the short run are driven solely by changes in capacity utilization. The division of profit income between productive and financial capitalists, in turn, depends on the stock of debt, $D$, of the former with the latter, with $\delta=D / K$ being the debt-capital ratio. Hence, the debt service, which is the portion of financial capitalists in profit income, is given by $i D$.

Therefore, the aggregate saving as a proportion of the capital stock is given by:

$$
g^{s}=s_{p} r+\left(s_{f}-s_{p}\right) i \delta
$$

which follows from our assumptions that workers do not save and productive and financial capitalists save constant fractions, $s_{p}$ and $s_{f}$, respectively, of their profit income.

The nominal interest rate, in turn, in line with Rousseas' (1985) suggestion to apply Kaleckian theory to the determination of bank loan rates, is set by banks as a markup over the base rate:

$$
i=h i^{*}
$$


where $h>1$ is the banking markup and $i^{*}$ is the base rate, which is exogenously set by the monetary authority. ${ }^{3}$ The base rate, the banking markup, and hence the nominal interest rate, are all predetermined at a given point in time. While the base rate remains unchanged throughout, the banking markup changes over time according to the level of economic activity with respect to an exogenous reference level, with both being measured by the rate of capacity utilization:

$$
\dot{h}=\theta\left(u-u_{r}\right)
$$

where $\dot{h}$ is the rate of change in banking markup, $(d h / d t), \theta$ is a positive or negative parameter and $u_{r}$ is the (exogenous) reference level of economic activity with which banks compare the actual level of economic activity when deciding about the markup over the base rate. ${ }^{4}$ Hence, banking markup is either procyclical or anticyclical depending on the sign of the parameter $\theta$. Given the reference capacity utilization, $u_{r}$, a positive (negative) $\theta$ will make for a procyclical (anticyclical) banking markup, in the sense that a higher actual capacity utilization by firms will raise (lower) the banking markup.

Given that the rates of capacity utilization, profit and growth move in the same direction, as shown in the next section, a rationale for an anticylical banking markup is the following. An increase in the rates of capacity utilization and profit raises firms' ability to serve outstanding financial obligations, lowers their perceived risk of default and, therefore, leads to a fall in the banking markup (e.g. Wolfson 1996). Another rationale would be that a fall in macroeconomic activity, by raising the liquidity preference of banks, will lead the banking system to raise the differential between the base rate and the lending rate (e.g. Lavoie 1992). As for a rationale for a procyclical banking markup, based on a intracapitalist conflict view, it could be claimed that a rise in macroeconomic activity, by reflecting more buoyant aggregate demand conditions, will lead the banking system to desire a higher share of the general flow of profits generated by the stock of physical capital.

The empirical evidence on the cyclical behavior of measures of the banking markup is ambiguous. For instance, Saunders \& Schumacher (2000) studied the determinants of bank interest margins in six selected European countries and the United States during the period 1988-95, having found that interest margins are positively affected by credit risk.

\footnotetext{
3 "Within Post Keynesian monetary economics, the demand for money is for financial credit primarily by the business sector. It is the flow of credit money that counts, not an exogenous stock of money. In this particular approach, the focus is on bank lending, or the asset side of the balance sheet. The liability side is seen as causally reacting to changes in the asset side. Portfolio theory is therefore downplayed and a Kaleckian approach to the banking industry becomes possible" (Rousseas, 1985, p. 135).

${ }^{4}$ See Lavoie (1995) for a comparative view of the manner through which post-keynesian models of growth and distribution incorporate money endogeneity and interest rate exogeneity. While the short-run side of the model developed here is similar to Lavoie's version of the newer Kaleckian model, its dynamic side does contribute to the post-keynesian approach by incorporating a flexible banking markup. While in all of the variants presented by Lavoie economic activity has no feedback effect on the rate of interest, in the model that follows capacity utilization has a dynamic feedback on the banking markup and hence on the interest rate. A detailed analysis of several post-keynesian views on money endogeneity is conducted in Meirelles (1998).
} 
Angbazo (1997), using data for a sample of North-American banks during the period 198993, found that the ratio of non-performing loans to total loans is a significant explanatory variable for banking spreads, having a positive impact on them. Aronovich (1994) used brazilian data for the period 1986-1992 and found significant evidence of a negative relation between capacity utilization and banking markup for interest rate on working capital, while Afanasieff, Lhacer \& Nakane (2001), now using brazilian data for the 19972000 period, found that the impact of output growth was to reduce the banking spread. According to the study conducted by Demirgüç-Kunt \& Huizinga (1999), using bank-level data for 80 countries in the years 1988-95, output growth does not seem to have any impact on bank spread, though. In turn, Brock \& Rojas-Suarez (2000) studied the determinants of banking spreads in six Latin American countries during the mid-1990s and found a more mixed evidence, with higher levels of non-performing loans having raised spreads in some countries, but having lowered them in others. This latter finding is tentatively explained by the authors as a result of inadequate provisioning for loan losses: higher non-performing loans would reduce banks' income, thereby lowering the spread in the absence of loan loss reserves. This study by Brock \& Rojas-Suarez (2000) also found a tendency, nonetheless weak, for higher output growth rates to lower the spread, which the authors claim that may reflect the fact that high growth generally raises the capitalized value of firms and reduces the cost of lending by lowering default risk.

\section{The behavior of the model in the short run}

The short run is here defined as a time span through which the capital stock, $K$, the nominal interest rate, $i$, and the stock of debt, $D$, can all be taken as given. The existence of excess productive capacity means that the macroeconomic equality between desired investment and saving is brought about by changes in output through changes in capacity utilization. ${ }^{5}$ Using eqs. (1), (4) and (5), we can solve for the short-run equilibrium value of $u$, given $V, i, \delta$ and parameters of the model:

$$
u^{*}=\frac{\alpha-\left[\gamma+\left(s_{f}-\mathrm{s}_{\mathrm{p}}\right) \delta\right] i}{\left(s_{p}-\beta\right)(1-V a)}
$$

Regarding stability, we employ a keynesian short-run adjustment mechanism stating that output will change in proportion to the excess demand in the goods market. Hence, $u^{*}$ will be stable provided the denominator of eq. (8) is positive, which we assume to be the

\footnotetext{
5 A post-keynesian macrodynamic model of distribution and growth that considers both cases regarding capacity utilization, namely full and less-than-full, is developed in Lima \& Meirelles (2003). Like in the model developed here, the supply of credit-money is endogenous and interest rate is set by the banking system as a markup over the base rate, which is exogenously determined by the monetary authority. Over time, banking markup falls with firms' profit rate on physical capital and rises with the inflation rate. The dynamic stability properties of the system are carefully analyzed for both cases regarding capacity utilization, which makes for the possibility of multiple equilibria for the state variables real wage and interest rate. Unlike the present model, however, firms' financing regime - and thus the financial fragility of the economy - is not modeled.
} 
case. ${ }^{6}$ We also assume that the numerator of $u^{*}$ is positive, which will ensure a positive value for $u^{*}$ itself.

Hence, a rise in the real wage will lead to an increase in capacity utilization. Like in the models developed by Rowthorn (1981) and Dutt (1984, 1990), an increase in the real wage, by redistributing income from capitalists who save to workers who do not, raises consumption demand, and therefore increases capacity utilization. However, this rise in the real wage will leave the general rate of profit unchanged, since it will lower the profit share in income in the same extent that it will raise capacity utilization. Indeed, the equilibrium value of the general profit rate, $r^{*}$, which can be obtained by substituting the expression for $u^{*}$ into eq. (4), is given by:

$$
r^{*}=\frac{\alpha-\left[\gamma+\left(s_{f}-\mathrm{s}_{\mathrm{p}}\right) \delta\right] i}{\left(s_{p}-\beta\right)}
$$

In turn, the impact of a change in the interest rate or in the debt-capital ratio on the short-run equilibrium values of capacity utilization and general profit rate is ambiguous:

$$
\begin{aligned}
& d u^{*} / d i=u_{i}^{*}=\frac{-\left[\gamma+\left(s_{f}-\mathrm{s}_{\mathrm{p}}\right) \delta\right]}{\left(s_{p}-\beta\right)(1-V a)} \\
& d r^{*} / d i=r_{i}^{*}=\frac{-\left[\gamma+\left(s_{f}-\mathrm{s}_{\mathrm{p}}\right) \delta\right]}{\left(s_{p}-\beta\right)} \\
& d u^{*} / d \delta=u_{\delta}^{*}=\frac{-\left(s_{f}-s_{p}\right) i}{\left(s_{p}-\beta\right)(1-V a)} \\
& d r^{*} / d \delta=r_{\delta}^{*}=\frac{-\left(s_{f}-s_{p}\right) i}{\left(s_{p}-\beta\right)}
\end{aligned}
$$

Eqs. (10)-(13) show that either a higher interest rate or a higher debt ratio will unambiguously lower the rates of capacity utilization and profit in case financial capitalists save a higher proportion of their profit income than productive capitalists do. A higher interest rate, for instance, will reduce demand not only by lowering desired investment, but by lowering consumption as well, as it will imply a intra-capitalist income redistribution towards those capitalists who save a higher proportion of their income. A higher debt ratio, in turn, despite not reducing desired investment directly, but only through the accelerator effect embodied in the $r$-argument, will reduce demand by redistributing profit income towards financial capitalists who consume relatively less than the productive capitalists do.

Now, only the impact of changes in the interest rate remains ambiguous when productive capitalists have a higher saving propensity than financial capitalists do. Indeed,

\footnotetext{
${ }^{6}$ Having assumed an adjustment mechanism given by $\dot{u}=d u / d t=\phi\left[g^{d}-g^{s}\right]$, where $\phi>0$ is the speed of adjustment, stability of $u^{*}$ requires $d \dot{u} / d t<0$. Since meaningful values for the profit share, $0<(1-V a)<1$, are as well required, the implied stability condition is given by $s_{p}>\beta$.
} 
eqs. (12)-(13) show that a higher debt ratio will unambiguously raise the rates of capacity utilization and profit in this case. The reason is that it will raise consumption demand by redistributing profit income towards those capitalists whose saving propensity is lower and, despite not raising desired investment directly, it will end up doing so indirectly through the accelerator effect. Regarding the impact of changes in the interest rate, eqs. (10)-(11) show that it will depend on the relative impact of two opposite effects. On the one hand, a higher interest rate will unambiguously raise consumption demand by redistributing profit income towards those capitalists whose saving rate is lower. On the other hand, this higher interest rate will have a negative immediate impact on desired investment. Hence, the rates of capacity utilization and profit will end up raising (falling) in case the relative impact of these two effects is such that aggregate demand ends up raising (falling). ${ }^{7}$

The corresponding growth rate of the capital stock, which is actually the growth rate of this one-good economy, can be obtained by substituting the equilibrium value of the general rate of profit, eq. (9), into either eq. (1) or eq. (5):

$$
g^{*}=\frac{s_{p}(\alpha-\gamma i)-\beta\left(s_{f}-\mathrm{s}_{\mathrm{p}}\right) \delta i}{\left(s_{p}-\beta\right)}
$$

which implies that the impact of changes in the interest rate or the debt ratio on the rate of growth is given by:

$$
\begin{aligned}
& d g^{*} / d i=g_{i}^{*}=\frac{-\left[s_{p} \gamma+\beta\left(s_{f}-\mathrm{s}_{\mathrm{p}}\right) \delta\right]}{\left(s_{p}-\beta\right)} \\
& d g^{*} / d \delta=g_{\delta}^{*}=\frac{-\beta\left(s_{f}-\mathrm{s}_{\mathrm{p}}\right) i}{\left(s_{p}-\beta\right)}
\end{aligned}
$$

Eqs. (15)-(16) show that a rise in the real wage, despite raising capacity utilization, will leave the growth rate unchanged. The reason, as seen above, is that this rise will leave the rate of profit unchanged. In turn, either a higher interest rate or a higher debt ratio, by lowering the rate of profit, will also lower the growth rate in case financial capitalists save a higher proportion of their profit income than productive capitalists do. Now, only the impact of changes in the interest rate on the growth rate remains ambiguous when productive capitalists have a higher saving propensity than financial capitalists do. Indeed, eq. (16) shows that a higher debt ratio, by raising the rate of profit, will raise the growth rate. Eq. (15), in turn, when compared to eq. (11), reveals that for a higher interest rate to end up raising the rate of growth, it is not sufficient that it raises the rate of profit along the way - recall that stability of all these short-run equilibrium values requires $s_{p}>\beta{ }^{8}$

\footnotetext{
${ }^{7}$ In case we had assumed that financial and productive capitalists share a common propensity to save, all of these ambiguities regarding the impact of a change in the interest rate would vanish. It can be checked that both capacity utilization and the general profit rate would unambiguously fall in response to a higher interest rate, while a change in the real wage would have the same qualitative impact as before. Besides, the equilibrium values of capacity utilization and the general profit rate would cease to depend on the debt ratio.

${ }^{8}$ In line with the preceding footnote, financial and productive capitalists sharing a common saving propensity would make for an unambiguously inverse relationship between the rates of interest and
} 


\section{Indebtedness and finance regimes}

Minsky's (1982) taxonomy of finance regimes in terms of a firm's cash flow accounting categories has been neatly formalized by Foley (2003) as follows. ${ }^{9}$ In a highly aggregated form, the cash flow identity equates the firm's source of funds from net operating revenues, $R$, and new borrowing, $B$, to its uses of funds for investment, $I$, and debt service, $F$ :

$$
R+B \equiv I+F
$$

Hence, the change in debt, $\dot{D}=d D / d t$, is given by new borrowing:

$$
\dot{D}=B=I+F-R
$$

Now, recalling that the growth rate is given by $g=I / K$, that the profit rate is given by the flow of profits as a ratio of the capital stock, $r=R / K$, and that the debt service is given by $i D$, we can express the change in debt as follows:

$$
\dot{D}=(g-r) K+i D
$$

The minskyan taxonomy, in turn, can be derived as follows:

Hedge: $R \geq I+F$ ou $B \leq 0$

Speculative: $R<I+F$ ou $I>B>0$

Ponzi: $R \leq F$ ou $B \geq I$

Now, using the definitions that led to eq. (19), and recalling that eq. (3) implies $r=r_{p}+i \delta$, our version of the minskyan taxonomy can then be expressed as follows:

\begin{tabular}{lcc}
\hline Financing regime & & \\
\hline Hedge & $r-i \delta \geq g$ & $r_{p} \geq g$ \\
Speculative & $r-i \delta<g$ & $r_{p}<g$ \\
Ponzi & $r-i \delta \leq 0$ & $r_{p} \leq 0$ \\
\hline
\end{tabular}

Actually, by combining these inequalities with the respective expressions for the equilibrium values for the rates of profit and growth, eqs. (9) and (14), and by assuming for simplicity that financial and productive capitalists share a common saving propensity, $s$, we can derive the corresponding demarcation lines in the $(i, \delta)$-space:

growth. While a change in the real wage would keep having no impact on the equilibrium growth rate, the latter would now become independent from the debt ratio.

9 According to Minsky's broad characterization, hedge financing units are those that can fulfill all of their contractual payment obligations by their cash flows, while speculative units are those that can meet their interest payment commitments on outstanding debts, even as they are unable to repay the principle out of income cash flows. For Ponzi units, in turn, the cash flow from operations are not enough to fulfill either the rapayment of principle or the interest due on outstanding debts. 


$$
\begin{aligned}
& \delta_{h-s}=\frac{(1-s) \alpha}{(s-\beta)} \frac{1}{i}-\frac{(1-s) \gamma}{(s-\beta)} \\
& \delta_{s-p}=\frac{\alpha}{(s-\beta)} \frac{1}{i}-\frac{\gamma}{(s-\beta)}
\end{aligned}
$$

where $\delta_{h-s}$ and $\delta_{s-p}$ are the debt levels corresponding to the regime transition from hedge to speculative, and from speculative to Ponzi, respectively, as shown in Figure $1 .^{10}$

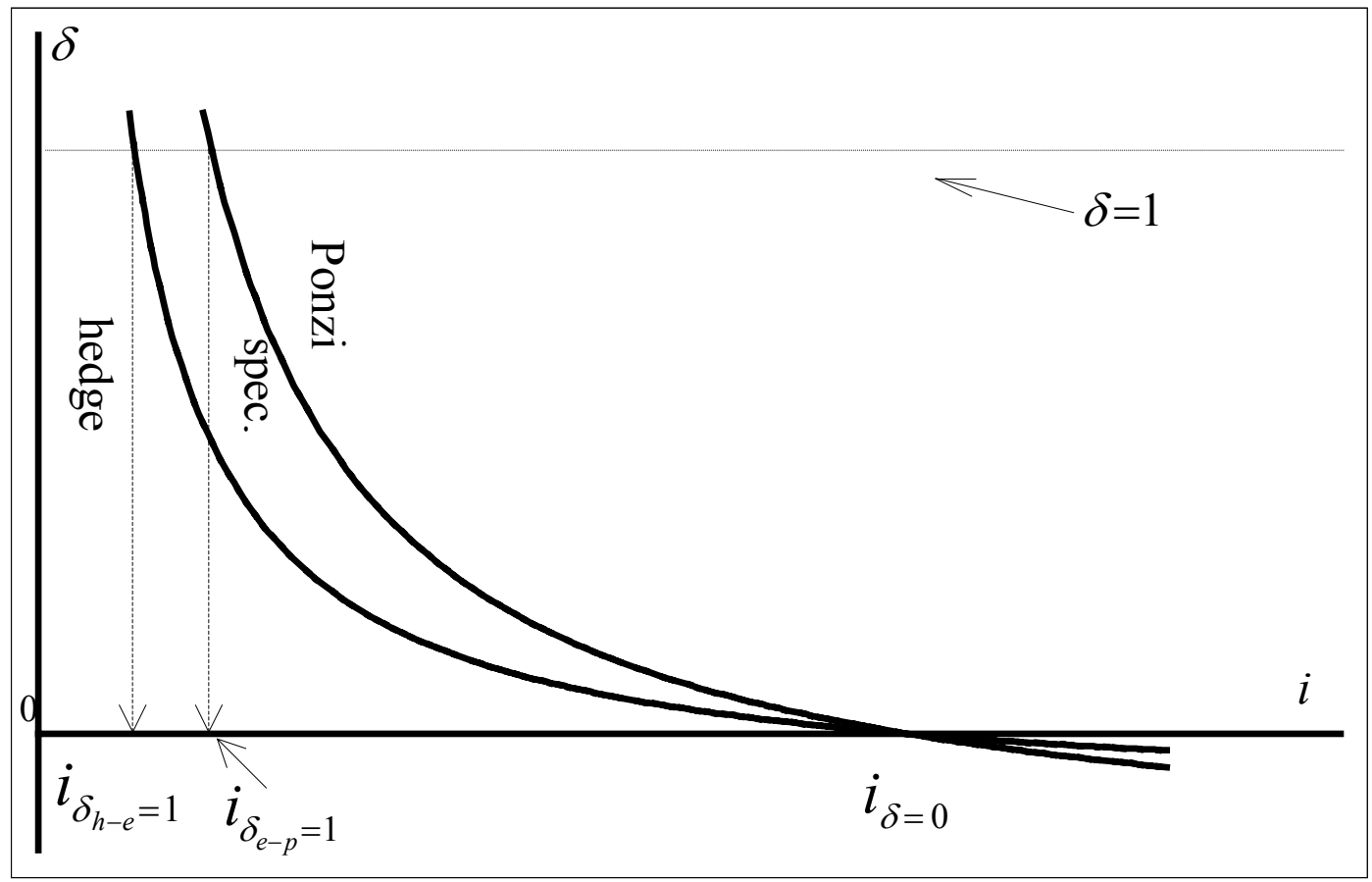

Figure 1 - Minskyan financing regimes in the $(i, \delta)$-space.

\footnotetext{
${ }^{10}$ Even though we built on Foley's (2003) interesting formalization of the minskyan regimes, and actually drew a lot of inspiration from the whole paper, our version of the corresponding taxonomy turned out a different one. Indeed, Foley claimed that a model - like Taylor \& O'Connell (1985) or, we should add, the one developed here - that maintains the closed economy Kaleckian relation between the growth rate and the savings out of profits, $g=s r$, which is eq. (5) above when it is assumed that productive and financial capitalists share a common saving propensity, does impose a regime of hedge finance in which $g<r$ in case it is assumed $s<1$. Foley's ingenious solution is the opening of the economy to capital inflows from abroad, which would allow the domestic growth rates to exceed the domestic profit rate. Hence, the model developed here, by distinguishing between productive and financial capitalists, to each one accruing a portion of the general rate of profit, provides a different solution to the issue raised by Foley - by allowing the growth rate to exceed the portion of the general profit rate that accrues to indebted productive capitalists. Indeed, Minsky himself did not rely on the opening of the economy to develop a taxonomy of finance regimes, having nonetheless built on Kaleckian profit equations.
} 
Note that for very low levels of debt these demarcation lines approach each other, with the lower limit of the debt ratio meaning an interest rate given by $i_{\delta=0}=\alpha / \gamma$. In turn, for a debt ratio given by $\delta=1$ the interest rate levels corresponding to the respective transition lines - from hedge to speculative and from speculative to Ponzi - are given by:

$$
\begin{aligned}
& i_{\delta_{h-s}=1}=\frac{\alpha(1-s)}{[(s-\beta)+\gamma(1-s)]} \\
& i_{\delta_{s-p}=1}=\frac{\alpha}{[(s-\beta)+\gamma]}
\end{aligned}
$$

What follows in the next section is a detailed analysis relating the dynamic stability properties of a system having the nominal interest rate and the debt ratio as state variables to the type of minskyan finance regime that prevails, given the structural parameters of the saving and investment functions - that is, given the size of the regime areas in the $(i, \delta)$ space, as shown in Figure 1. ${ }^{11}$ First of all, we have to delimitate the sub-space of validity of the present model in that space, though. In addition to being greater than or equal to zero, $i$ and $\delta$ should also be constrained with respect to their maximum values, so as to ensure positive equilibrium values for the rates of capacity utilization, profit and growth - which requires $i \leq \alpha / \gamma$, as we assumed that financial and productive capitalists share a common saving propensity.

\section{The behavior of the model in the long run}

In the long run we assume that the short-run equilibrium values of the endogenous variables $u, r$ and $g$ are always attained, with the economy moving over time due to changes in the capital stock, $K$, the stock of debt, $D$, and the nominal interest rate, $i$. We therefore analyse the intertemporal, long-run behavior of the economy by examining the dynamics of the debt to capital ratio and the nominal interest rate. Using eqs. (6) and (7) for the interest rate, and from the definition of the debt to capital ratio, we have the following two-dimensional, autonomous dynamic sistem:

$$
\begin{aligned}
& \dot{i}=d i / d t=i^{*} \theta\left(u-u_{r}\right) \\
& \dot{\delta}=d \delta / d t=(g-r)+\delta(i-g)
\end{aligned}
$$

\footnotetext{
${ }^{11}$ In Meirelles \& Lima (2004), in turn, we analyze the impact of changes in all of these structural parameters on the propensity of such an economy to be located in each one of the minskyan finance regimes, given the interest rate and the debt ratio. Unlike the present model, however, no dynamic analysis is developed. Amongst other interesting results, it is found that while the propensity to a hedge regime rises with a higher sensitivity of investment to interest rate, the propensity to a Ponzi regime falls with it. In turn, while the propensity to a hedge regime rises with a higher sensitivity of investment to the profit rate, the propensity to a Ponzi regime falls with it. As it turns out, the accompanying impact of a higher sensitivity of investment to the profit rate (interest rate) on capacity utilization and growth is positive (negative), so that a more financially robust economy do not (do) come at the cost of a lower level and growth of economic activity.
} 
where $u, r$ and $g$ are given by eqs. (8), (9) and (14), respectively, under the assumption that productive and financial capitalists have a common saving propensity out of their profit income. The corresponding matrix of partial derivatives is given by:

$$
\begin{aligned}
& J_{11}=\partial \dot{i} / \partial i=i^{*} \theta u_{i}^{*} \\
& J_{12}=\partial \dot{i} / \partial \delta=0 \\
& J_{21}=\partial \dot{\delta} / \partial i=(1-\delta) g_{i}^{*}+\delta-r_{i}^{*}=\frac{\gamma(1-s)+\delta(\gamma s+s-\beta)}{(s-\beta)}>0 \\
& J_{22}=\partial \dot{\delta} / \partial i=i-g
\end{aligned}
$$

Not all of these partial derivatives can be unambiguously signed, though. Eq. (29) shows that with $u_{i}^{*}<0$, given the assumption of capitalists having a common propensity to save, the sign of $J_{11}$ will happen to be negative in case the banking markup is procyclical (anticyclical), that is, in case $\theta>0(\theta<0)$. Regarding the sign of $J_{12}$, the reason is that the change in banking markup is not influenced by the level of the debt ratio (cf. fn. 7). In turn, the positive sign for $J_{21}$ is due to the rise (fall) in the stock of debt (capital) brought about by an increase in the rate of interest. Finally, the sign of $J_{22}$ depends on the relative levels of the rates of interest and growth, with a change in sign taking place whenever the $i-g=0$ frontier is crossed. Using eq. (14), under the assumption of a common propensity to save by capitalists, the value of the interest rate corresponding to this frontier is given by:

$$
i_{i=g^{*}}=\frac{\alpha s}{(s-\beta+\gamma s)}
$$

Now, a comparison between eqs. (33) and (26) shows that the $i-g=0$ frontier is actually located to the left of the Ponzi area in Figure 1, given the restrictions required for positive and stable equilibrium values for the rates of capacity utilization, profit and growth to obtain $(0<\beta<s \leq 1)$. In turn, a comparison bewteen eqs. (33) and (25) indicates that the $i-g=0$ frontier will as well be located to the left of the speculative area in case $s<0.5$, and might be located to the right of a fraction of the top part of the speculative area in case $s>0.5$. All of these possibilities are pictured in Figure 2. 


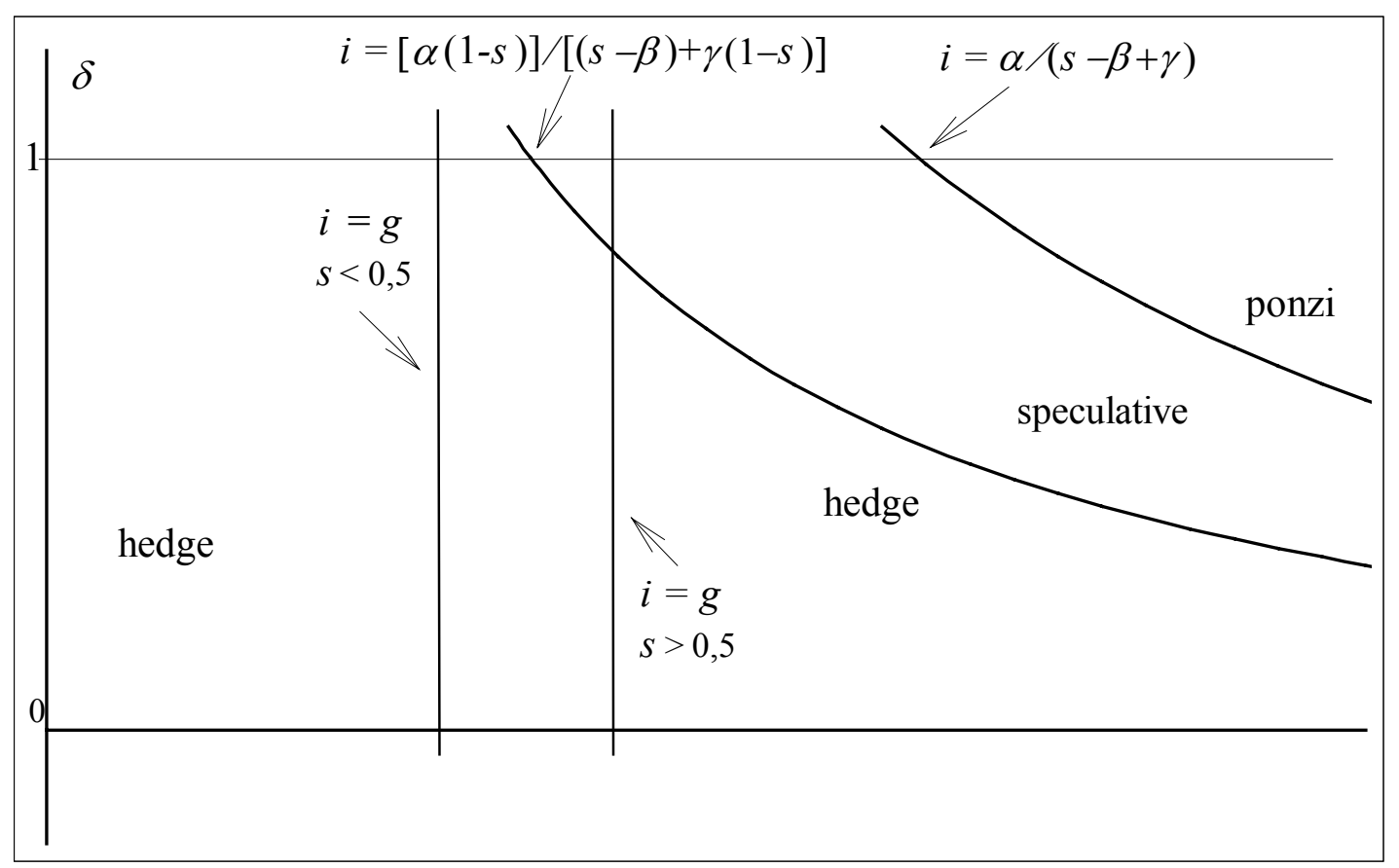

Figure 2 - Location of the $i-g=0$ frontier

Let us analyze the stability properties of a long-run equilibrium solution located in the hedge area. As seen above, a procyclical banking markup will make for a negative sign for $J_{11}$. Combined with a situation in which $i<g$, which implies $J_{22}<0$, a procyclical markup will therefore make for a positive sign for the determinant of the matrix given by eqs. (29)-(32), $\operatorname{Det}(J)$, and for a negative sign for the corresponding trace, $\operatorname{Tr}(J)$. Such a stable equilibrium with $\dot{i}=\dot{\delta}=0$ is pictured in Figure 3.

An anticyclical banking markup, however, with which the sign of $J_{11}$ becomes positive, will make for a negative sign for $\operatorname{Det}(J)$, and therefore for a saddle-point unstable equilibrium with $\dot{i}=\dot{\delta}=0$ no matter the sign of $\operatorname{Tr}(J)$. Such an instability is pictured in Figure 4. When combined with a situation in which $i>g$, which implies $J_{22}>0$, an anticyclical banking markup will make for a positive sign for $\operatorname{Det}(J)$, which is a necessary condition for stability. To the extent, however, that it will make for a positive sign for $\operatorname{Tr}(J)$, such a long-run equilibrium in the hedge financing area will be unstable. In turn, a procyclical banking markup, when combined with a situation given by $i>g$, will make for a negative $\operatorname{Det}(J)$, and therefore for a saddle-point unstable equilibrium no matter the sign of $\operatorname{Tr}(J)$. 


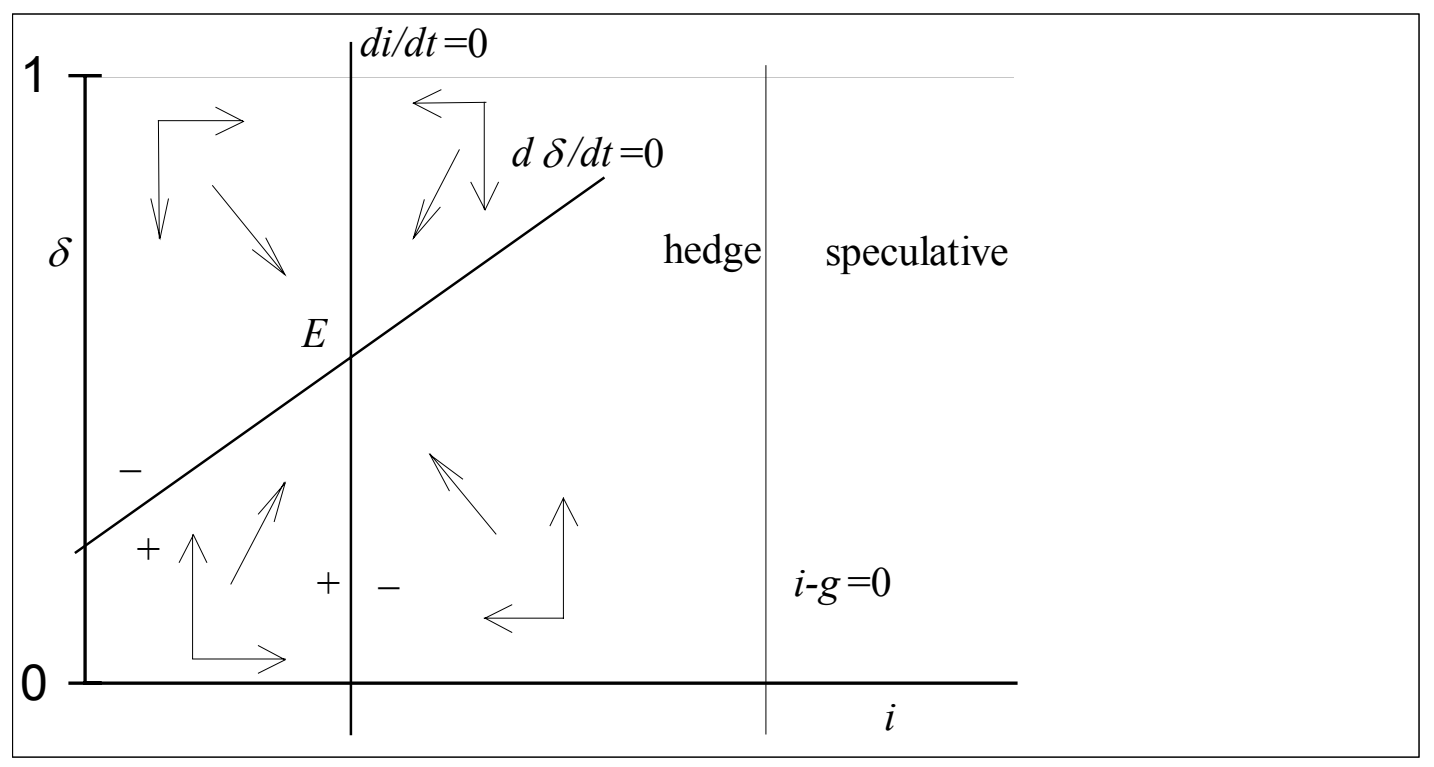

Figure 3 - Stable equilibrium in a hedge financing regime

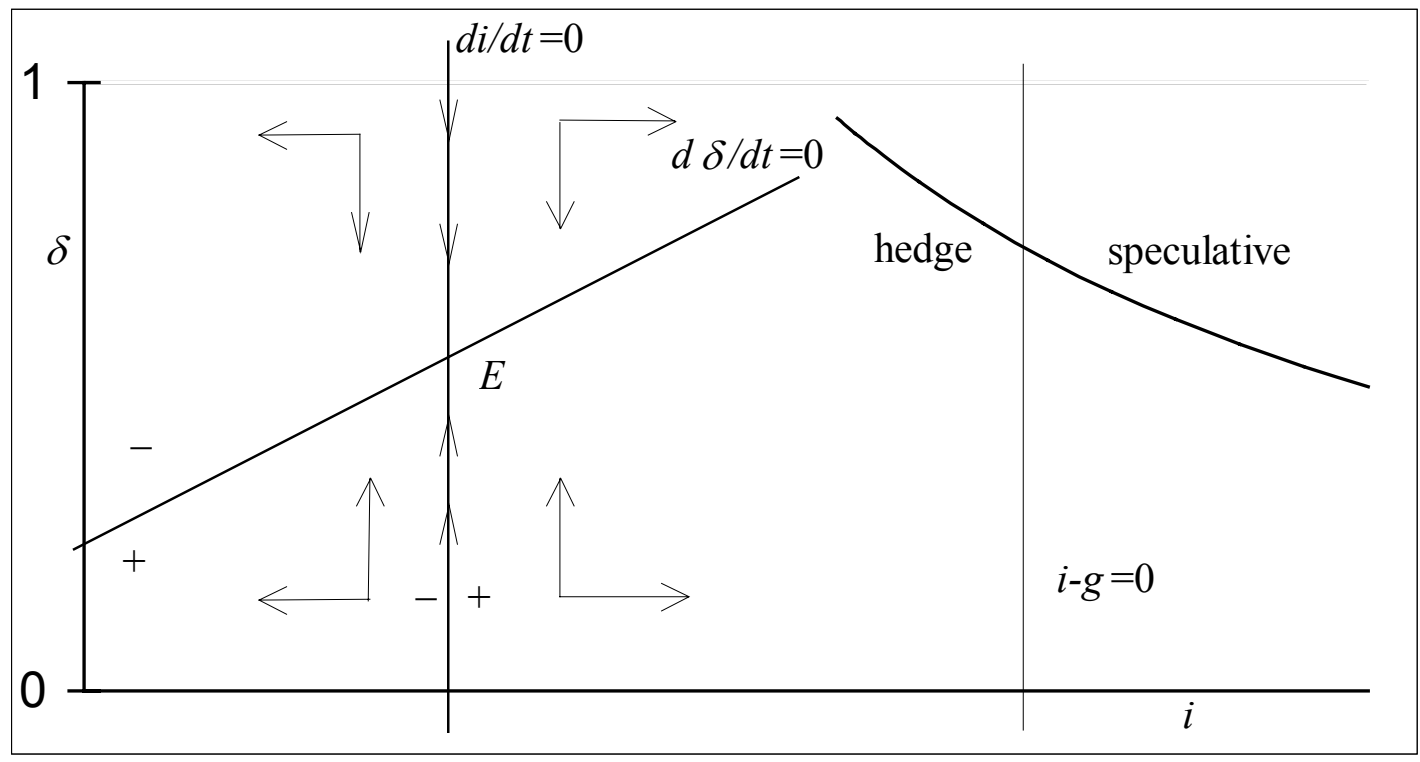

Figure 4 - Saddle-point instability in a hedge financing regime

Interestingly, therefore, a long-run equilibrium solution located in the hedge area will be necessarily stable only in case banking markup is procyclical and $i<g$. In turn, an anticyclical banking markup will make for an unstable long-run equilibrium solution no matter the relative size of the rates of interest and growth.

Regarding a long-run equilibrium solution located in the speculative area, in turn, its stability properties depend not only on the cyclical behavior of the banking markup, but on the saving propensity by capitalists as well. Indeed, a sufficiently low saving propensity by capitalists, $s<0.5$, will preclude a long-run equilibrium solution with $i<g$ to be located in the speculative area, as shown in Figure 2. In such a case, long-run equilibrium will be 
necessarily unstable. Provided capitalists' propensity to save is sufficiently high, $s>0.5$, therefore, similar stability possibilities to those that arouse for the hedge area will present themselves for the speculative area. Again, a long-run equilibrium solution located in this area will be necessarily stable only in case banking markup is procyclical and $i<g$, while an anticyclical banking markup will make for an unstable long-run equilibrium solution no matter the relative size of the rates of interest and growth.

To the extent that the sign of the partial derivative given by $J_{22}$ depends upon the relative levels of the rates of interest and growth, with a change in sign taking place when the $i-g=0$ frontier is crossed, let us analyze more carefully the specification for the rate of interest adopted here. By integrating eq. (7) and substituting the resulting expression in eq. (6), we obtain:

$$
i(t)=i^{*} \phi+i^{*} \theta \int_{t}\left(u-u_{r}\right) d t
$$

were $\phi$ is a constant term in the formation of the banking markup. Hence, the interest rate is comprised by a constant term, $i^{*} \phi$, and a variable component which oscillates according to the difference between the actual and the reference capacity utilization. Starting from a situation pictured in Figure 3, for instance, a decision either by the monetary authority to raise the base interest rate or by the banking system to raise the constant component of its markup may lead to the crossing of the $i-g=0$ frontier. Indeed, in both cases this frontier would be approached from the left, which can be shown by combining eqs. (33) and (34):

$$
i-g=\frac{(s-\beta+\gamma s) \phi i^{*}}{(s-\beta)}+\frac{(s-\beta+\gamma s) \theta i^{*}}{(s-\beta)} \int_{t}\left(u-u_{r}\right) d t-\frac{\alpha s}{(s-\beta)}
$$

As pictured in Figure 2, the parametric restrictions required for positive and stable equilibrium values for the rates of capacity utilization, profit and growth to obtain imply that the $i-g=0$ frontier is necessarily located to the left of the Ponzi area. Therefore, a long-run equilibrium solution with $\dot{i}=\dot{\delta}=0$ located in the ponzi area will be unstable no matter either the propensity to save by capitalists or the cyclical behavior of the banking markup. A procyclical banking markup will make for a negative $\operatorname{Det}(J)$ and hence for a saddle-point long-run equilibrium no matter the sign of $\operatorname{Tr}(J)$, as pictured in Figure 5. In turn, an anticyclical behavior of banking markup, despite making for a positive $\operatorname{Det}(J)$, which is a necessary condition for stability, makes for a positive $\operatorname{Tr}(J)$ as well. This latter instability is pictured in Figure 6. 


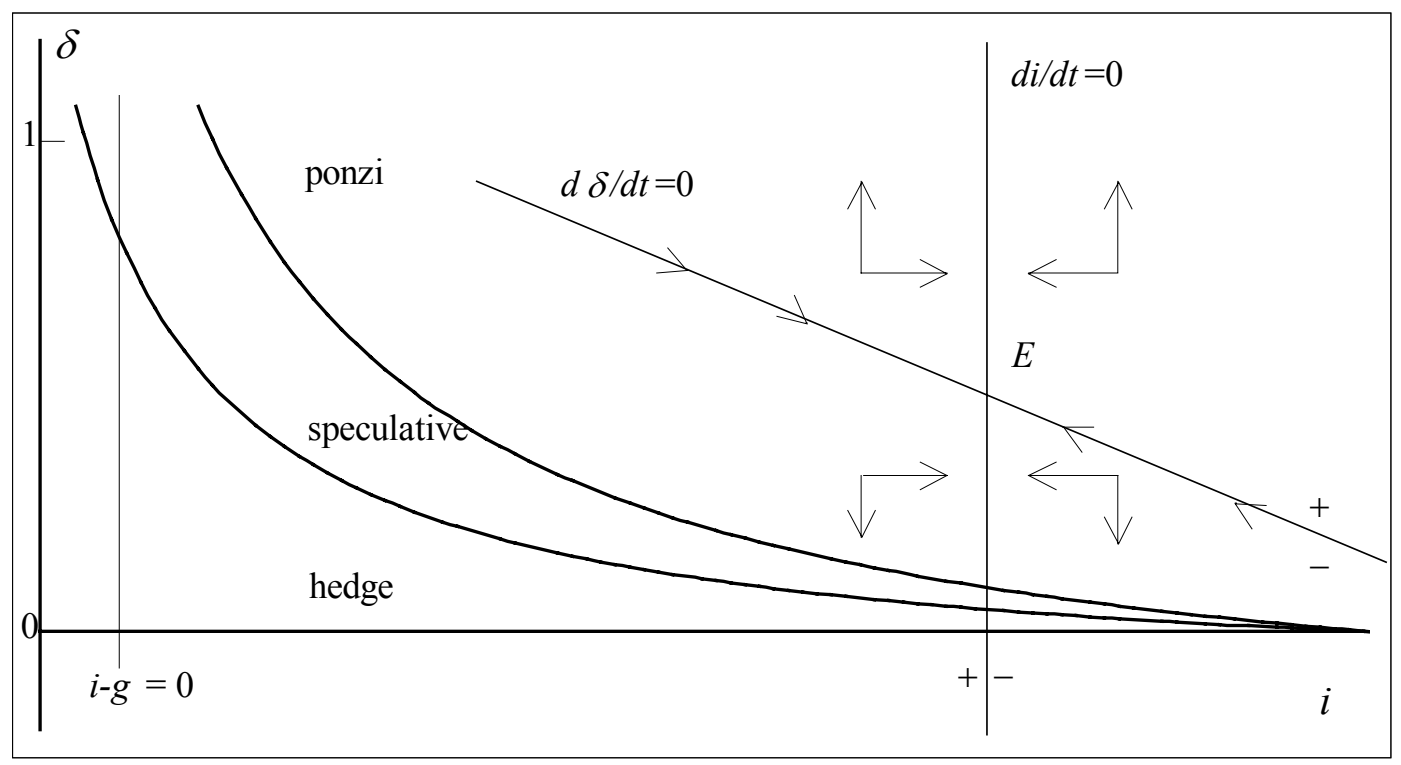

Figure 5 - Saddle-point instability in a ponzi financing regime

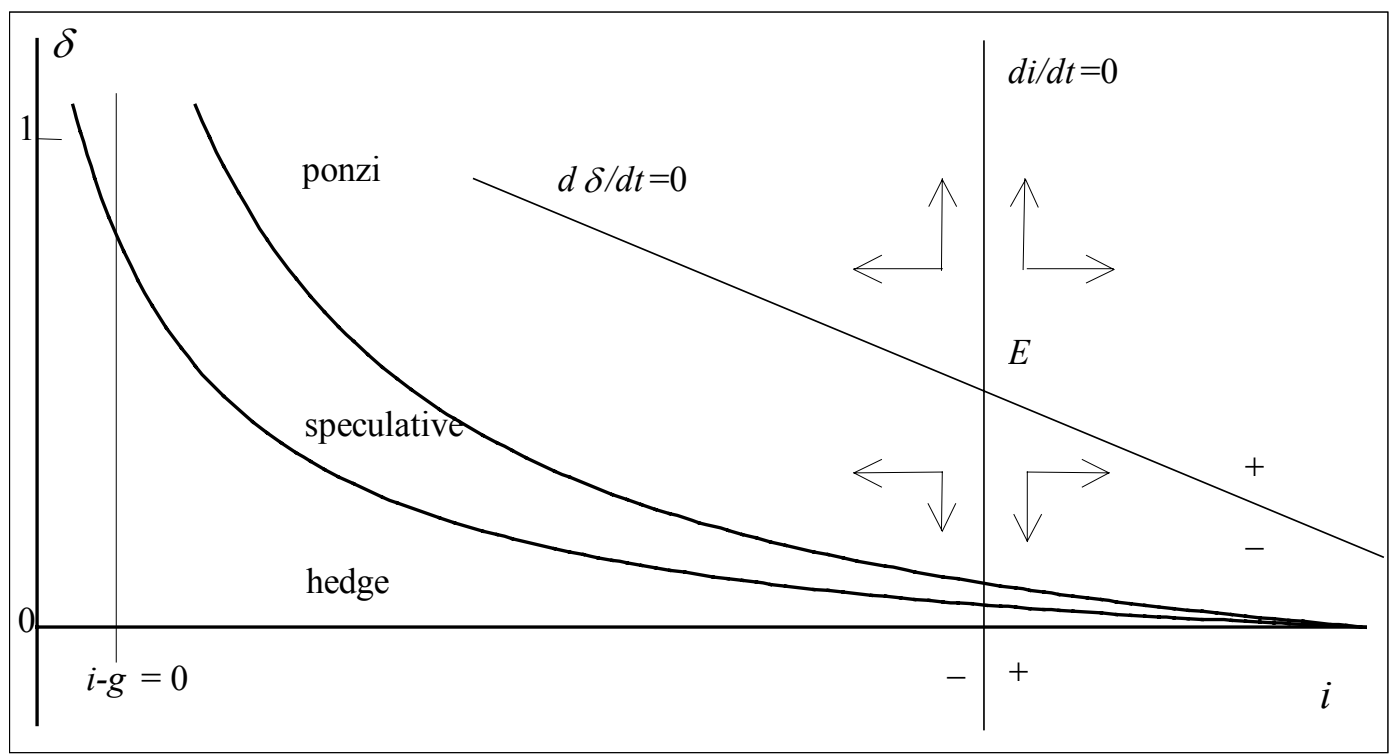

Figure 6 - Unstable equilibrium in a ponzi financing regime

\section{Conclusion}

This paper developed a dynamic macromodel of capacity utilization and growth, in which the supply of credit-money by the banking system is endogenous, demand-driven at a given nominal interest rate. Moreover, firms' debt position with the banking system - and therefore the financial fragility of the economy - was explicitly modeled.

Production decisions being made according to effective demand, it was considered only the case in which there is not enough demand to ensure full capacity utilization. Firms' investment, in turn, was assumed to depend positively on the profit rate and negatively on 
interest rate. As a result of the process by which investment by firms was assumed to be financed, the liabilities on their balance sheet would determine a series of prior payment commitments, while their assets would generate a series of conjectured cash inflows.

In this context, a rise in the real wage will lead to an increase in capacity utilization. An increase in the real wage, by redistributing income from capitalists who save to workers who do not, raises consumption demand, and thus increases productive capacity utilization. However, this rise in the real wage will leave the general rate of profit unchanged, since it will lower the profit share in income in the same extent that it will raise capacity utilization. In turn, the impact of a change in the interest rate or in the debt-capital ratio on the shortrun equilibrium values of capacity utilization and general profit rate is ambiguous. A higher interest rate or a higher debt ratio will unambiguously lower the rates of capacity utilization and profit in case financial capitalists save a higher proportion of their profit income than productive capitalists do. Now, only the impact of changes in the interest rate remains ambiguous when productive capitalists have a higher saving propensity than financial capitalists do. Indeed, a higher debt ratio will unambiguously raise the rates of capacity utilization and profit in this case.

However, a rise in the real wage, despite raising capacity utilization, will leave the growth rate unchanged. The reason is that this rise will leave the general rate of profit unchanged. In turn, either a higher interest rate or a higher debt ratio, by lowering the general rate of profit, will lower the growth rate as well in case financial capitalists save a higher proportion of their profit income than productive capitalists do. Now, only the impact of changes in the interest rate on the growth rate remains ambiguous in the event productive capitalists have a higher saving propensity than financial capitalists do. Indeed, a higher debt ratio, by raising the rate of profit, will raise the growth rate.

Besides, it was formally derived a version of the minskyan taxonomy of financing regimes (hedge, speculative, ponzi) by firms. What then followed was a detailed analysis relating the dynamic stability properties of a system having the nominal interest rate and the debt ratio by firms as state variables to the type of minskyan regime prevalent in the productive sector.

Interestingly, a long-run equilibrium solution located in the hedge finance area will be necessarily stable only in case banking markup is procyclical and the interest rate is lower than the growth rate. In turn, an anticyclical banking markup will make for an unstable long-run equilibrium solution no matter the relative size of the rates of interest and growth.

Regarding a long-run equilibrium solution located in the speculative area, in turn, its stability properties depend not only on the cyclical behavior of the banking markup, but on the saving propensity by capitalists as well. A propensity to save low enough will make for a necessarily unstable long-run equilibrium. Provided capitalists' propensity to save is high enough, stability possibilities similar to those for the hedge area will arise. Again, a longrun equilibrium will be necessarily stable only in case banking markup is procyclical and the interest rate is lower than the growth rate, while an anticyclical banking markup will make for an unstable long-run equilibrium no matter the relative size of the rates of interest and growth. 
Finally, it was derived that a long-run equilibrium solution located in the ponzi area will be unstable no matter the propensity to save by capitalists or the cyclical behavior of the banking markup.

\section{$\underline{\text { References }}$}

AFANASIEFF, T., LHACER, P. M. V. \& NAKANE, M. (2002) "The determinants of bank interest spread in Brazil". Money Affairs, 15(2), jul-dec.

ANGBAZO, L. (1997) "Commercial bank net interest margins, default risk, interest-rate risk, and off-balance sheet banking”. Journal of Banking and Finance, 21.

ARONOVICH, S. (1994) "Uma nota sobre os efeitos da inflação e do nível de atividade sobre o spread bancário”. Revista Brasileira de Economia, 48(1).

BROCK, P. \& ROJAS-SUAREZ, L. (2000) "Understanding the behavior of bank spreads in Latin America". Journal of Development Economics, Vol. 63.

DEMIRGÜÇ-KUNT, A. \& HUIZINGA, H. (1999) "Determinants of commercial bank interest margins and profitability: some international evidence". The World Bank Economic Review, 13(2).

DUTT, A. K. (1984) "Stagnation, income distribution and monopoly power". Cambridge Journal of Economics, vol. 8, no. 1.

DUTT, A. K. (1990) Growth, distribution and uneven development. Cambridge: Cambridge University Press.

DUTT, A. K. (1994) “On the long-run stability of capitalist economies: implications of a model of growth and distribution". in: A. K. DUTT (ed) (1994) New Directions in Analytical Political Economy. Aldershot: Edward Elgar.

FOLEY, D. (2003) "Financial fragility in developing economies". In: DUTT, A. K. \& ROS, J. (eds) Development Economics and Structuralist Macroeconomics. Aldershot: Edward Elgar.

FOLEY, D. \& MICHL, T. (1999) Growth and distribution. Cambridge: Harvard University Press.

KALDOR, N. (1956) "Alternative theories of distribution". Review of Economic Studies, vol. 23 , no. 2 .

KALECKI, M. (1971) Selected essays on the dynamics of the capitalist economy. Cambridge: Cambridge University Press.

LAVOIE, M. (1992) Foundations of Post-Keynesian Economic Analysis. Aldershot: Edward Elgar.

LAVOIE, M. (1995) "Interest rates in post-keynesian models of growth and distribution". Metroeconomica, vol. 46, no. 2.

LIMA, G. T. (2000) "Market concentration and technological innovation in a macrodynamics of growth and distribution". Banca Nazionale del Lavoro Quarterly Review, Vol. LIII, No. 215, December. 
LIMA, G.T. (2003) "Endogenous technological innovation, capital accumulation and distributional dynamics". Metroeconomica, forthcoming (in 2004).

LIMA, G.T. \& MEIRELLES, A. J. A. (2003) "Endogenous banking markup, distributional conflict and capacity utilization". Metroeconomica, 54(2\&3), May/September.

MEIRELLES, A. J. A (1998) Moeda e produção: uma análise da polêmica pós-keynesiana sobre a endogenia monetária. Campinas: Mercado de Letras, São Paulo: Fapesp.

MEIRELlES, A. J. A. \& LIMA, G. T. (2004) "Debt, financial fragility and economic growth: a post-keynesian macromodel", mimeo. Presented at the conference Economic Growth and Distribution: On the Nature and Causes of the Wealth of Nations, Lucca (Italy), June 16-18, 2004 (http://growth-distribution.ec.unipi.it/).

MINSKY, H. (1975) John Maynard Keynes. New York: Columbia University Press.

MINSKY, H. (1982) Can "it” happen again? Essays on instability and finance. New York: M. E. Sharpe.

PASINETTI, L. (1962) "The rate of profit and income distribution in relation to the rate of economic growth”. Review of Economic Studies, vol. 29, no. 4.

ROBINSON, J. (1962) Essays in the Theory of Economic Growth. London: Macmillan.

ROUSSEAS, S. (1985) "A markup theory of bank loan rates". Journal of Post Keynesian Economics, 8(1).

ROWTHORN, B. (1981) "Demand, real wages and economic growth". Thames Papers in Political Economy, Autumn.

SAUNDERS, A. \& SCHUMACHER, L. (2000) "The determinants of bank interest rate margins: an international study". Journal of International Money and Finance, 19.

STEINDL, J. (1952) Maturity and Stagnation in American Capitalism. New York: Monthly Review Press.

TAYLOR, L. \& O’CONNELL, S. (1985) “A Minsky crisis”. Quarterly Journal of Economics, 100

WOLFSON, M. (1996) "A post-keynesian theory of credit rationing". Journal of Post Keynesian Economics, 18(3), Spring. 